Journal of Social Sciences 8 (1): 22-28, 2012

ISSN 1549-3652

(C) 2012 Science Publications

\title{
Sungai Mas and OC-EO Glass Beads: A Comparative Study
}

\author{
${ }^{1}$ Zuliskandar Ramli, ${ }^{1}$ Nik Hassan Shuhaimi Nik Abd. Rahman and ${ }^{2}$ Adnan Jusoh \\ ${ }^{1}$ Institute of the Malay World and Civilisation, \\ University Kebangsaan Malaysia, 43600 UKM Bangi Selangor, Malaysia \\ ${ }^{2}$ History Department, Faculty of Human Sciences, \\ Sultan Idris Education University, 35900 Tanjong Malim, Perak
}

\begin{abstract}
Problem statement: Sungai Mas, Kedah, Malaysia and OC-EO, Vietnam, was two of the Indo-Pacific beads making centre's in Southeast Asia. The drawn monochrome glass beads or IndoPacific beads industry begun in Arikamedu, India since 200BC was identified by Ptolemy as Poduca Emporium, with the presence of a small colony of Roman merchants. Arikamedu was abandoned by the 3rd century and before it was abandoned, the bead making centre was transferred to three other sites by the 2nd century CE which are Sri Lanka, Klong Thom, Thailand and OC-EO, Vietnam. Sungai Mas served as Indo-Pacific beads making centre by the 6th century CE until 13th century CE. Therefore the objective of this research is to determine from the beads compositional aspect whether beads from Sungai Mas originated from OC-EO or not. This is to prove that Sungai Mas and OC-EO produce their own beads. Approach: The study approach is base on compositional aspect of the beads. Compositional aspects of the beads involve their major and trace elements. Secondary data involved major and trace elements of the beads from Sungai Mas and OC-EO were analyzed based on their percentage of total and concentration. Results: Based on major and trace elements content showed that Sungai Mas beads are differ from OC-EO beads. This can be seen from the high percentage of silica, silver and fluks in Sungai Mas beads compare to lower percentage of those elements in OC-EO beads. Conclusion: The results showed that Sungai Mas and OC-EO produced their own glass beads and they were two of the Indo-Pacific beads-making centre in Southeast Asia beginning from 2nd century CE to 13 th century CE.
\end{abstract}

Key words: Indo-Pacific beads, Sungai Mas, OC-EO, monochrome glass beads

\section{INTRODUCTION}

Indo-Pacific beads can be defined as a small, monochrome drawn bead of rather dull and limited colours which were the most common trade item in Africa and Asia for some 2500 years. They are found in tens of thousands from South Korea to South Africa and Mali to Bali (Francis, 2002). In Malaysia, IndoPacific beads can be found in largely scale at Sungai Mas, Kedah (5th century CE to 18th century CE) and Kuala Seining, Perak while in Vietnam, it can be found in OC-EO, an ancient port kingdom of Fun a dated from 1 st century CE to 7 th century CE.

These beads have been discussed by many scholars, some giving names that are still current. Van Der Sleen (1956) coined 'Trade Wind Beads' for both the drawn and wound beads which crossed the Indian Ocean to East Africa. Davidson (1972) adopted the term and further defined them as the 'Trade Wind Beads Chemical Group' with trace of uranium. The differences between drawn and wound beads are so profound that there is no justification for grouping them together. They were made at different places and must be considered separately (Francis Jr., 1989).

Lamb, (1965) introduced English readers to the Malay term 'mutisalah' or translated into the English language as false pearl for the opaque red drawn beads. Van Der Sleen (1966) considered the mutisalah beads stated by Lamb not as drawn beads but wound beads with high content of lead reaching $40 \%$ which can be classified as lead glass. Statements from both men were correct because the Timorese call any small opaque red or orange bead mutisalah, whether drawn or wound (Francis Jr., 1989). The drawn one is Indo-Pacific beads; the wound ones are Chinese "coil" beads. Again, these two must be considered separately and there is no reason to concentrate on one or two colours at the expense of the other similar beads (Francis Jr., 1989).

Francis Jr. (1989) then introduced a new defined name for these beads in order to evade any confusion from other beads especially wound beads. Francis

Corresponding Author: Zuliskandar Ramli' Institute of the Malay World and Civilisation, University Kebangsaan Malaysia, 43600 UKM Bangi Selangor 
classified the beads "Indo-Pacific Beads" short for "Indo-Pacific Monochrome Drawn Glass Beads" indicating their distribution, color, manufacturing method and material. They are further defined as beads made from tubes drawn from the 'lade' method.

Many scholars have discussed these beads, usually attempting to discover where they were made. This was never really successful; most guessed they were from India. Despite a vigorous archaeological agenda in India, no site has ever been found which could possibly have made and exported so many beads over such a long time. Only Lamb (1965) saw further when he wrote:

"One is tempted to postulate...the existence of something like a nomadic bead making group, perhaps of Indian origin, which established itself at various South-east Asian centres where a bead demand existed."

It has long been recognized that these beads were made at Arikamedu (250 BC-250 CE), on the southeast coast of India, near Pondicherry. Similar beads are currently made in Papanaidupet and hra Pradesh using a unique method. Francis have documenting the modern process and comparing the remains with those from Arikamedu the inescapable conclusion is that the two places made/make beads in the same manner Francis Jr. (1989).

Indo-pacific bead-makers: The bead industry began at Arikamedu; almost from its founding, there is no evidence of earlier drawn bead making. The city was a flourishing port for more than five centuries and it was identified by Ptolemy as Produce emporium, with the presence of a small colony of Roman merchants. It was abandoned by the 3rd century A.D., likely overrun by the Kalahari, which the Tamil Sang am literature depicts as 'barbarians' (Irāmacāmi, 1987). Before it was abandoned beads-making was transferred to three other sites by the 2 nd century CE.

- $\quad$ Mantai, Sri Lanka (1st-10th century CE), the major transfer point for ships from the West and the East and easternmost terminal of Western sailor. It is identified with Modutti emporium

- Klong Thom, in Southern Thailand (2nd to 6th century CE), the western port for the trans-isthmus trade across the Kra Peninsula. Recent find of Roman glass beads and a Han bronze mirror suggest that this was the spot near Trang identified by Braddell and widely accepted as Ptolemy's Takkola emporium

- OC-EO, Vietnam (2nd 7th century CE), the portkingdom of Fun an, the major stop between Malay Peninsula and the Far East Solheim
(1963). Solheim and others are inclined to identify it with Ptolemy's Kattigara emporium.

All three sites show affinity with each other and with Arikamedu. The bead evidence alone (Indo-Pacific beads-making, stone beads-making, the presence of Roman beads and intrusive trade) indicates that Francis Jr. (1989).

Mantai sold beads to the west through the Arab and Persians and were probably the first to reach Africa. OC-EO may have served the prestigious of East Asian markets. The Annals of Wu (A.D 222-280) says that Fun an envoys presented Liu-li or opaque glass to the Wu court at Nanjing. Opaque glass here would not be referring to vessels; the only opaque glass made in Funan was Indo-Pacific beads. The History of Liang (A.D. 502-566) says that King Rudravaram sent tributes to Nanjing in 519, which seem to have included glass beads (Pelliot, 1903). The presents sent by the King of Peaches in Korea to the Japanese court in 543 may have contained beads from Fun an, where the merchandise was bought Bachmann (1982). Certainly, Indo-Pacific beads were fit for royalty; the Korean kings of Paekche and Silla were buried with tens of thousands of them Francis Jr. (1985). The market for Klong Thom beads may have been Southeast Asia. Perhaps beads from Klong Thom reached Gilimanuk, Bali and supplied the Philippine and Borneo sites. Analyses will help to confirm or revise these suggested market structures.

OC-EO was overrun by the Khmers in the late 6th or early 7th centuries CE; Klong Thom was abandoned at about that time. We have no further information on the making of these beads in Indochina. It may have continued under the Khmers, but possibly it did not. On the Malaya peninsula however, the industry did survive. In southern Thailand, Sating Pra (7-10th centuries) became an Indo-Pacific bead-maker. It was related to OC-EO and like OC-EO, it built canals for inland transportation, even linking the South China and the Andaman Seas. It was a large city of perhaps 110,000 people-Khmers, Tamils and Malays-and an important link in the Srivijaya system (Bentley, 1986).

Francis Jr. (1989) have suggested that Kuala Seining, Perak, produced Indo-Pacific beads from 7 th century AD to 10 th century AD. An island at the mouth of the Seining River, it was not an ideal port. Its beads were sent northwards to Kedah, the Merbok Valley with its excellent harbour in the shadow of Kedah Peak (Gunung Jerai) and visible $50 \mathrm{~km}$ out to sea. Kedah was the region's great emporium. Stressed its connections with Trang (Klong Thom). Thus, it may be that bead makers from OC-EO settled in Sating Pra, while those from Klong Thom settled at Kuala Seining Francis, (2002). 
Recent archaeological excavation that has been done in Kuala Seining showed another interesting fact. Based on $\mathrm{C}^{14}$ dating, it showed that the settlement was occupied since 200BC and several samples at different level of depth then have been send for $\mathrm{C}^{14}$ dating test. The result showed dating from $1810 \pm 40-1450 \pm 40 \mathrm{BP}$. We suggest that Kuala Selinsing or Pulau Kelumpang produced Indo-Pacific beads since 2 nd century $\mathrm{CE}$ the same period as Mantai, Klong Thom and OC-EO. This statement is based on the observations of soil stratigraphy where the beads were found and associated with the results the $\mathrm{C}^{14}$ analysis that was conducted results. Kuala Selinsing served the demands of Indo-Pacific beads from the Malay Peninsula, Sumatera, Java, Borneo and Bali Ramli et al. (2009).

In the 10th or early 11 th century all the bead making sites shifted, perhaps due to the Chola invasions. Mantai was destroyed by the Cholas and the bead makers settled again in southern India. J. Lavanaha in 1593 said the Portuguese went to India to buy beads because they were the only ones wanted in East Africa; they were made in Negapatam (Nagapattinam), from where they were brought to Mozambique (Theal, 1898). Francis Jr. (1989) conducted a surface survey and devoted ten man-hours covering the old city at Nagapattinam (1988), but no evidence for glassmaking/working was uncovered. The bead makers were probably near rather than at the city and moved to Papanaidupet later.

Kuala Seining was abandoned in about the 11 th century; ecological factors may have played a part (there are now eleven islands where one once was), or it may have been attacked by the Cholas. However the port settlement was still being used by the local people but not as important as before. The bead makers probably move to Sungai Mas in the 8th century AD but we believe not all bead makers from Kuala Seining moved to Sungai Mas, only some of them. It is probably because the demand of beads was so high in the region and the facts that Sungai Mas was a very developed entrepot and flourishing kingdom. Archaeological evidences showed that Sungai Mas evolved as a port-kingdom in the 5th century AD. This is based on finding such as Sungai Mas inscription, votive tablets and Sungai Mas inscription 2 .

One other place in southern Thailand, Takua $\mathrm{Pa},(9$ and 10th centuries CE) also made these beads. The late remains there indicate that it should not be identified with Ptolemy's Takkola. Given the date for IndoPacific bead-making, it may be that the workers came from Sating Pra.

By the 13th century Indo-Pacific bead making had ceased in Southeast Asia. Why this happened is not fully understood. Arab power begins to be felt and the bead evidence shows intense Arab trade along Malaya. Chinese beads are much in evidence east of Malaya and perhaps competition speeded the decline of the industry.

That the Southeast Asian Indo-Pacific bead making industry died at this time is clear. There are no known beads makers later than the 13th century; Sungai Mas was the last, but no beads are found in levels with Ming pottery (from 1368). Moreover, importing sites in the Philippines and Sarawak from the 13th century had no Indo-Pacific beads, which had dominated until them; they are completely replaced by wound beads, likely to be Chinese Francis Jr. (1989).

A few remarks are appropriate for the Philippines. If for no other reason than the large presence of IndoPacific beads, the terminal date for the Early Metal Age should be brought down to the first few centuries A.D. The date of 200 B.C. follows Fox's chronology. There appears to be a resurgence of Indo-Pacific beads in the Late Phase of the Age of Trade and Contact with the East. This is probably illusionary. They were found at only three sites, two of which accounted for $82.5 \%$. These sites are early, dated to the 14 and15th centuries and could be earlier still. The others come from Calatagan, a very large cemetery that certainly had a longer period of use than Fox suggested. At least one bead there (a large orange disc) is an heirloom.

These caveats aside, the evidence from the two importing areas of the Philippines and Sarawak indicate that Indo-Pacific beads were gone in these regions sometime during the South or Late Song Period, at a medium date of A.D. 1200 Francis, (2002).

\section{MATERIALS AND METHOD}

The type of data used was secondary data mainly from previous publications whether published from journals or books. Analysis of OC-EO beads involved X-Ray Fluorescence Spectroscopy technique while Sungai Mas beads involved X-Ray Fluorescent Ramli et al. (2011) and Neutron Activation Analysis Rahman et al. (2008) techniques. X-ray Fluorescence Spectroscopy (XRF) were a very useful instrument to analyzed major and trace elements of ceramics, soils, sediement and etc (Sharmin et al., 2010; Hamzah et al., 2011; Abdullah et al., 2011)

The type of analytical technique that was employed in this research was descriptive and comparative analysis. In presenting the relevant data, we made use of table and their percentage of dry weight and also their concentration. It help in analyzing the study and result very well so that we would have clear understanding of the research and also it made the usage of these tables and figure to explained in a clear way Sola and Fatukasi (2011) 


\section{RESULTS AND DISCUSSION}

Analyses of indo-pacific beads: Indo-Pacific beads were made at several sites over a long period. Bead makers do not need to make glass to make beads. Broken glass can be recycled and glass "cakes" have been articles of commerce for millennia. Given that there are several possible origins for Indo-Pacific bead glass, various questions arise.

The first is whether the glass for Indo-Pacific beads was imported from outside, in particular the West. An earlier study in which analyses of these beads was compared with glass from various of Western sources showed that glass of Indo-Pacific beads is unlike any contemporary Western glasses. The results from the SLOWPOKE-Toronto analyses confirm that assessment Francis Jr. (1989).

This leaves us with other questions. If the glass was made within the Indo-Pacific bead making system, where was it produced? Was it made in one place and exported to other bead making sites? Were there regional glassmaking centres? Did each bead making locale make its own glass?

OC-EO (Table 1) in the first to seventh centuries was one of the first sites outside India to make IndoPacific beads Francis (2002). The results showed only one element of alkalies that is sodium and no potassium content. The difference in alkalies between different colours at Arikamedu and Karaikadu is important. As the alkalies were not separated at Oc Eo, the alkalies in beads cannot be compared. The high percentages reported for sodium at Oc Eo are too high, so we suggested that the contents reported are for both alkalies. They are never less than $20 \%$ and in two cases are over one-fourth of the total elements. The combined alkali figure in all other Indo-Pacific beads reaches $20 \%$ in only two beads and then just barely.

The silver concentration of OC-EO beads is high. Turner and Rooksby (1959), discussing Western glasses, said that alumina is commonly present in amounts of $1-5 \%$. He noted only three exceptions
(1.85\% of his samples) having more: 7.2, 9.8 and $14.5 \%$. Seven of the eleven Oc Eo specimens have more than $5.0 \%$ and three exceed $10.0 \%$. No Arikamedu glass approaches have these high levels. The OC-EO dark blue glasses were not coloured with the potash-manganese-cobalt combination. Based on the elemental content of OC-EO glass beads it's showed that Arikamedu did not make glass for OC-EO Francis (2002).

Table 2 showed the contents of major elements in the Sungai Mas Indo-Pacific beads. The results indicate that beads and three samples suspected as raw material have relatively high amount of silica that is more than $60 \%$. Content of sodium is also high that is in the range of $14.08-18.53 \%$ whilst potassium in the range of 1.54$2.12 \%$. This signified that the Indo-Pacific beads a drawn beads and of soda glass type. This data is in agreement to the previous report by Hancock et al. (1994) and Rahman et al. (2008) that most drawn beads are of soda glass rather than potash glass type. The content of lead also confirms that Sungai Mas beads are Indo-Pacific beads and not lead glass beads which originated from China.

The silver content in Sungai Mas beads is also relatively high that is in range of $7.79-13.52 \%$.

The concentration of silver in Sungai Mas beads samples that have been done by Rahman et al. (2008) Table 4 showed lower silver content that is in the range of $1.08-6.96 \%$. The elevated amount of silver is also noticeable from samples of Sungai Mas, in which 17 out of 24 samples consist of silver higher than $5 \%$ Rahman et al. (2008). No Arikamedu glass approaches have these high levels of silver and it showed that Sungai Mas made their own glass beads. The relatively high silver has also shown in some of the glass beads from Kuala Selinsing, Klong Thom of Thailand and OC-EO of Vietnam Francis (2002).

Table 1: Glass analysis (percentage of total) from OC-EO

\begin{tabular}{|c|c|c|c|c|c|c|c|c|c|}
\hline Bead colour & $\mathrm{SiO}_{2}$ & $\mathrm{Na}_{2} \mathrm{O}$ & $\mathrm{CaO}$ & $\mathrm{Fe}_{2} \mathrm{O}_{3}$ & $\mathrm{Al}_{2} \mathrm{O}_{3}$ & $\mathrm{CuO}$ & $\mathrm{MnO}$ & $\mathrm{MgO}$ & Other \\
\hline Dark red & 59.3 & 20.60 & 3.60 & 1.59 & 9.40 & 2.30 & 0.13 & 1.81 & $\mathrm{~S}=0.89$ \\
\hline Orange red & 55.5 & 20.92 & 3.80 & 4.31 & 6.33 & 5.27 & 0.09 & 1.88 & $\mathrm{~S}=1.30, \mathrm{Co}=$ trace \\
\hline Dark blue & 59.4 & 23.34 & 10.80 & 0.64 & 2.16 & 0.63 & 0.03 & 2.60 & $\mathrm{Co}=$ trace \\
\hline Dark blue & 61.0 & 23.90 & 8.00 & 1.20 & 3.42 & - & 0.14 & 1.44 & $\mathrm{Co}=$ trace \\
\hline Light blue & 61.9 & 22.95 & 3.20 & 0.80 & 8.79 & 1.26 & 0.08 & 1.15 & $\mathrm{~S}=0.37, \mathrm{Co}=$ trace \\
\hline Yellow & 58.6 & 25.04 & 3.80 & 0.48 & 10.02 & & 0.08 & 0.57 & $S=0.61$ \\
\hline Bright yellow & 57.2 & 22.42 & 4.00 & 0.48 & 12.54 & 0.31 & 0.11 & 1.66 & $S=0.68$ \\
\hline Greenish yellow & 59.5 & 21.70 & 3.00 & 0.64 & 11.61 & 0.63 & 0.11 & 1.73 & - \\
\hline Light green & 56.4 & 20.35 & 5.80 & 0.48 & 4.84 & - & 0.04 & 1.44 & $\mathrm{~S}=0.75$ \\
\hline Translucent green & 62.2 & 26.45 & 5.40 & 0.48 & 2.46 & - & 0.04 & 2.17 & - \\
\hline Black & 63.5 & 22.81 & 3.60 & 0.80 & 6.90 & trace & - & 0.57 & $\mathrm{~S}=1.02$ \\
\hline
\end{tabular}

Sources: Solheim (1963); Francis (2002) 
J. Social Sci., 8 (1): 22-28, 2012

Table 2: Content of major elements (percentage of total) in Sungai Mas Indo-pacific beads

\begin{tabular}{|c|c|c|c|c|c|c|c|c|c|}
\hline Bead colour & $\mathrm{SiO}_{2}$ & $\mathrm{Na}_{2} \mathrm{O}$ & $\mathrm{K}_{2} \mathrm{O}$ & $\mathrm{CaO}$ & $\mathrm{Fe}_{2} \mathrm{O}_{3}$ & $\mathrm{Al}_{2} \mathrm{O}_{3}$ & $\mathrm{TiO}_{2}$ & $\mathrm{MnO}$ & $\mathrm{MgO}$ \\
\hline Yellow & 67.37 & 14.56 & 1.86 & 2.16 & 1.85 & 8.87 & 0.53 & 0.08 & 0.45 \\
\hline Green & 63.09 & 15.40 & 1.93 & 3.27 & 2.00 & 9.46 & 0.56 & 0.08 & 1.05 \\
\hline Black & 66.22 & 17.04 & 1.91 & 2.31 & 2.39 & 9.11 & 0.44 & 0.05 & 1.25 \\
\hline Translucent blue & 65.36 & 17.34 & 1.99 & 2.65 & 1.38 & 7.79 & 0.49 & 0.06 & 0.64 \\
\hline Orange & 60.36 & 14.84 & 1.98 & 2.47 & 3.04 & 12.04 & 0.61 & 0.06 & 1.47 \\
\hline Translucent blue & 66.35 & 15.90 & 2.01 & 2.69 & 1.80 & 8.29 & 0.53 & 0.07 & 0.87 \\
\hline Translucent blue & 62.88 & 18.48 & 1.94 & 2.83 & 1.79 & 9.94 & 0.53 & 0.08 & 1.16 \\
\hline Light green & 63.90 & 16.36 & 1.76 & 2.54 & 1.96 & 9.83 & 0.52 & 0.08 & 1.15 \\
\hline Translucent Blue & 66.25 & 18.17 & 1.50 & 3.07 & 1.63 & 8.21 & 0.30 & 0.05 & 0.82 \\
\hline Red (opaque) & 64.50 & 15.77 & 1.75 & 2.88 & 2.74 & 10.29 & 0.50 & 0.06 & 0.96 \\
\hline Light yellow* & 64.37 & 14.08 & 1.98 & 2.27 & 1.72 & 9.59 & 0.59 & 0.07 & 0.73 \\
\hline Yellow & 64.82 & 16.87 & 1.97 & 2.08 & 1.70 & 9.84 & 0.52 & 0.07 & 0.92 \\
\hline Blue & 68.81 & 16.64 & 1.72 & 2.09 & 1.67 & 8.08 & 0.49 & 0.06 & 0.95 \\
\hline Green & 65.64 & 16.51 & 2.14 & 2.25 & 1.70 & 9.88 & 0.53 & 0.06 & 0.90 \\
\hline Light yellow* & 65.60 & 15.40 & 2.02 & 2.43 & 1.91 & 9.14 & 0.59 & 0.07 & 0.46 \\
\hline Red (opaque) & 62.16 & 17.70 & 2.12 & 2.86 & 2.03 & 11.05 & 0.53 & 0.07 & 0.85 \\
\hline Translucent blue & 62.66 & 17.78 & 1.87 & 2.73 & 1.87 & 9.95 & 0.52 & 0.07 & 1.25 \\
\hline Black & 65.30 & 18.53 & 2.06 & 2.17 & 1.43 & 11.20 & 0.56 & 0.07 & 0.88 \\
\hline Green & 67.60 & 16.33 & 1.90 & 3.13 & 2.06 & 9.70 & 0.54 & 0.07 & 0.92 \\
\hline Light yellow* & 58.46 & 18.31 & 1.54 & 3.10 & 1.38 & 11.99 & 0.60 & 0.05 & 0.82 \\
\hline Translucent blue & 64.21 & 17.72 & 1.85 & 3.03 & 1.36 & 9.20 & 0.45 & 0.05 & 0.67 \\
\hline Brown & 61.48 & 14.64 & 1.96 & 3.12 & 3.83 & 13.52 & 0.60 & 0.08 & 1.69 \\
\hline
\end{tabular}

*: Raw material: Source: Ramli et al. (2011)

Table 3: Contents of trace elements ( $\mathrm{ppm})$ in Sungai Mas Indo-Pacific beads

\begin{tabular}{|c|c|c|c|c|c|c|c|c|c|}
\hline Bead colour & $\mathrm{Cu}$ & $\mathrm{Pb}$ & $\mathrm{Zr}$ & $\mathrm{Sr}$ & $\mathrm{Ba}$ & $\mathrm{La}$ & $\mathrm{U}$ & $\mathrm{Ni}$ & $\mathrm{Cr}$ \\
\hline Yellow & $<10$ & 5386 & 387 & 284 & 247 & 79 & 33 & $<10$ & 64 \\
\hline Green & 2529 & 6634 & 519 & 381 & 271 & 67 & 11 & $<10$ & 85 \\
\hline Black & 45 & 154 & 314 & 426 & 132 & 96 & 15 & $<10$ & 111 \\
\hline Translucent blue & 5254 & 95 & 558 & 429 & 241 & 92 & 14 & $<10$ & 53 \\
\hline Orange & 13938 & $<10$ & 348 & 446 & 327 & 96 & 11 & 48 & 79 \\
\hline Translucent blue & 4049 & 69 & 616 & 415 & 254 & 57 & $<10$ & 19 & 60 \\
\hline Translucent blue & 3789 & 244 & 638 & 504 & 267 & 70 & $<10$ & $<10$ & 58 \\
\hline Light green & 2668 & 6454 & 527 & 404 & 267 & 80 & 12 & $<10$ & 62 \\
\hline Translucent blue & 5295 & 104 & 522 & 611 & 152 & 77 & $<10$ & $<10$ & 88 \\
\hline Red (opaque) & 2661 & $<10$ & 708 & 248 & 673 & 51 & 15 & $<10$ & 85 \\
\hline Light yellow* & 17 & $<10$ & 490 & 458 & 390 & 70 & 18 & $<10$ & 86 \\
\hline Yellow & 171 & 6533 & 490 & 467 & 303 & 74 & 29 & $<10$ & 98 \\
\hline Blue & 3976 & 111 & 584 & 398 & 240 & 70 & 18 & $<10$ & 64 \\
\hline Green & 2196 & 6424 & 510 & 360 & 283 & 64 & 30 & $<10$ & 53 \\
\hline Light yellow* & $<10$ & $<10$ & 758 & 976 & 277 & 62 & 25 & $<10$ & 84 \\
\hline Red (opaque) & 2240 & $<10$ & 578 & 795 & 398 & 68 & $<10$ & $<10$ & 86 \\
\hline Translucent blue & 3264 & 64 & 649 & 481 & 275 & 82 & 11 & $<10$ & 69 \\
\hline Black & $<10$ & 746 & 701 & 764 & 341 & 34 & 24 & $<10$ & 65 \\
\hline Green & 2368 & 4078 & 499 & 422 & 251 & 60 & 27 & $<10$ & 64 \\
\hline Light yellow* & $<10$ & $<10$ & 779 & 1029 & 296 & 67 & $<10$ & $<10$ & 59 \\
\hline Translucent blue & 6187 & 18 & 343 & 361 & 247 & 80 & 12 & $<10$ & 40 \\
\hline Brown & 14587 & 268 & 337 & 240 & 318 & 75 & 20 & 50 & 92 \\
\hline
\end{tabular}

*raw material: Source: Ramli et al. (2011)

Table 4: Content of major elements in indo-pacific beads from $\mathrm{Sg}$ Mas, butane valley

\begin{tabular}{|c|c|c|c|c|c|c|c|c|}
\hline Sample ID & Colour & $\mathrm{Ti}(\%)$ & $\operatorname{Mg}(\%)$ & $\mathrm{Al}(\%)$ & $\mathrm{Ca}(\%)$ & $\mathrm{Cl}(\%)$ & $\mathrm{K}(\%)$ & $\mathrm{Na}(\%)$ \\
\hline $1239 \mathrm{~A}$ & Black & $<0.01$ & 0.26 & 5.58 & 2.23 & 0.40 & 2.54 & 16.70 \\
\hline $1239 \mathrm{~B}$ & Red (opq) & $<0.01$ & 0.49 & 5.70 & 2.33 & 0.29 & 2.15 & 16.20 \\
\hline $1239 \mathrm{C}$ & Green (opq) & $<0.01$ & $<0.01$ & 5.11 & 1.83 & 0.32 & 2.30 & 16.30 \\
\hline $1239 \mathrm{Da}$ & Blue green & $<0.01$ & 1.18 & 5.13 & 2.42 & 0.25 & 1.86 & 18.20 \\
\hline $1239 \mathrm{Db}$ & Green & $<0.01$ & $<0.01$ & 5.66 & 1.99 & 0.22 & 2.10 & 15.60 \\
\hline $1239 \mathrm{E}$ & Yellow (opq) & $<0.01$ & 0.15 & 5.18 & 2.04 & 0.34 & 2.09 & 16.70 \\
\hline $1239 \mathrm{~F}$ & Green-blue & $<0.01$ & 0.07 & 5.73 & 4.40 & 0.21 & 1.99 & 20.70 \\
\hline $331 \mathrm{~A}$ & Blue & $<0.01$ & 3.14 & 1.08 & 2.52 & 0.20 & 2.51 & 10.20 \\
\hline $331 \mathrm{~B}$ & Red (opq) & 0.83 & 0.34 & 5.45 & 2.46 & 0.25 & 1.53 & 14.30 \\
\hline $331 \mathrm{C}$ & Orange (opq) & $<0.01$ & $<0.01$ & 6.21 & 2.24 & 0.23 & 1.56 & 11.10 \\
\hline $331 \mathrm{D}$ & Yellow (opq) & $<0.01$ & 3.11 & 2.36 & 4.24 & 0.23 & 3.22 & 11.30 \\
\hline $331 \mathrm{E}$ & Green (opq) & $<0.01$ & 0.80 & 3.22 & 3.25 & 0.26 & 1.40 & 9.84 \\
\hline $331 \mathrm{~F}$ & Black & 0.53 & 0.75 & 4.74 & $<0.01$ & 1.05 & 2.05 & 13.10 \\
\hline
\end{tabular}


Table:4. Continuous

\begin{tabular}{|c|c|c|c|c|c|c|c|c|}
\hline $331 \mathrm{G}$ & Dark blue & $<0.01$ & 194 & 173 & $<0.01$ & 0.83 & 2.29 & 11.00 \\
\hline $331 \mathrm{Ha}$ & Orange + Blac & q) 0.27 & 0.70 & 5.44 & $<0.01$ & 1.24 & 1.64 & 12.30 \\
\hline $331 \mathrm{Hb}$ & Orange (opq) & 0.36 & 0.64 & 5.62 & $<0.01$ & 1.03 & 1.46 & 12.30 \\
\hline $331 \mathrm{I}$ & White & $<0.01$ & 2.07 & 2.19 & $<0.01$ & 0.90 & 2.19 & 12.50 \\
\hline $331 \mathrm{~J}$ & Blue (opq) & $<0.01$ & 1.11 & 2.61 & $<0.01$ & 0.79 & 2.05 & 11.60 \\
\hline $90 \mathrm{~A}$ & Green & 0.33 & $<0.01$ & 5.55 & 2.66 & 1.09 & 1.57 & 16.50 \\
\hline $90 \mathrm{~B}$ & Red (opq) & 0.35 & 0.92 & 6.96 & $<0.01$ & 1.45 & 2.21 & 16.70 \\
\hline $90 \mathrm{D}$ & Brown & 0.39 & 1.02 & 6.12 & $<0.01$ & 1.57 & 1.65 & 11.30 \\
\hline $90 \mathrm{E}$ & Yellow (opq) & 0.39 & 0.64 & 6.37 & $<0.01$ & 1.18 & 2.13 & 13.80 \\
\hline $90 \mathrm{~F}$ & Green-blue & 0.35 & 0.89 & 5.27 & 2.83 & 0.49 & 1.64 & 16.10 \\
\hline $90 \mathrm{G}$ & Blue & 0.36 & 0.94 & 5.01 & $<0.01$ & 0.95 & 1.49 & 16.30 \\
\hline
\end{tabular}

Sample labelling: opq = opaque: Source: Rahman et al. (2008)

Table 5: Contents of elements known to be used as colorants and opacifiers of Indo-Pacific glass beads from Sg Mas, Bujang Valley

\begin{tabular}{|c|c|c|c|c|c|c|c|c|}
\hline Sample ID & Colour & $\mathrm{Fe}(\%)$ & $\mathrm{Mn}(\mathrm{ppm})$ & $\mathrm{Zn}(\mathrm{ppm})$ & Co (ppm) & $\mathrm{Cr}(\mathrm{ppm})$ & As (ppm) & $\mathrm{Sb}(\mathrm{ppm})$ \\
\hline $1239 \mathrm{~A}$ & Black & 1.87 & 488 & 39.4 & 7.24 & 54.6 & 5.34 & 1.49 \\
\hline $1239 \mathrm{~B}$ & Red (opq) & 1.87 & 534 & 43.1 & 12.40 & 46.0 & 9.16 & 1.87 \\
\hline $1239 \mathrm{C}$ & Green (opq) & 1.23 & 510 & 26.6 & 8.09 & 30.5 & 8.81 & 2.33 \\
\hline $1239 \mathrm{Da}$ & Green-blue & 1.05 & 483 & 33.9 & 7.61 & 29.3 & 13.40 & 3.39 \\
\hline $1239 \mathrm{Db}$ & Green & 1.47 & 571 & 33.7 & 9.33 & 32.5 & 9.86 & 2.22 \\
\hline $1239 \mathrm{E}$ & Yellow (opq) & 1.24 & 482 & 27.1 & 5.87 & 34.1 & 10.30 & 3.56 \\
\hline $1239 \mathrm{~F}$ & Blue green & 0.94 & 675 & 18.1 & 4.40 & 25.2 & 12.60 & 5.00 \\
\hline $331 \mathrm{~A}$ & Blue & 0.97 & 789 & 6390.0 & 2210.00 & 60.0 & $<0.10$ & 1.44 \\
\hline $331 \mathrm{~B}$ & Red (opq) & 1.77 & 442 & 37.5 & 9.93 & 49.8 & 21.10 & 7.05 \\
\hline $331 \mathrm{C}$ & Orange (opq) & 1.72 & 393 & 282.0 & 37.70 & 49.5 & 64.20 & 84.00 \\
\hline $331 \mathrm{D}$ & Yellow (opq) & 0.95 & 9600 & 27.8 & 6.87 & 37.2 & 85.80 & 3.65 \\
\hline $331 \mathrm{E}$ & Green $(o p q)$ & 1.36 & 1060 & 1380.0 & 9.19 & 41.9 & 580.00 & 176.00 \\
\hline $331 \mathrm{~F}$ & Black & 15.20 & 3140 & 110.0 & 41.40 & 42.2 & 4.63 & 0.73 \\
\hline $331 \mathrm{G}$ & Dark blue & 0.36 & 5430 & 101.0 & 394.00 & 37.6 & 24.00 & 3.91 \\
\hline $331 \mathrm{Ha}$ & Orange + Black (opq) & 1.04 & 426 & 28.4 & 4.87 & 25.0 & $<0.10$ & 0.24 \\
\hline $331 \mathrm{Hb}$ & Orange (opq) & 1.42 & 406 & 43.1 & 33.50 & 24.6 & 19.20 & 5.88 \\
\hline $331 \mathrm{I}$ & White & 0.19 & 1280 & $<0.1$ & 5.70 & 21.4 & 11.60 & $<0.10$ \\
\hline $331 \mathrm{~J}$ & Blue (opq) & 0.44 & 301 & 508.0 & 6.14 & 34.5 & 184.00 & 64.40 \\
\hline $90 \mathrm{~A}$ & Green & 2.40 & 517 & 40.5 & 23.70 & 41.0 & 24.40 & 8.05 \\
\hline $90 \mathrm{~B}$ & Red (opq) & 1.71 & 556 & 41.8 & 8.83 & 47.7 & 12.10 & 2.05 \\
\hline $90 \mathrm{D}$ & Brown & 1.55 & 725 & 36.1 & 5.89 & 25.7 & 11.40 & 1.22 \\
\hline $90 \mathrm{E}$ & Yellow (opq) & 1.06 & 474 & 35.4 & 4.30 & 18.1 & 6.97 & 1.05 \\
\hline $90 \mathrm{~F}$ & Green-blue & 1.24 & 528 & 31.0 & 4.71 & 28.3 & 13.90 & 6.59 \\
\hline $90 \mathrm{G}$ & Blue & 1.18 & 2620 & 29.5 & 11.70 & 26.5 & 12.60 & 3.53 \\
\hline
\end{tabular}

Source: Rahman et al. (2008)

Table 3 shows the contents of trace elements in the Sungai Mas Indo-Pacific beads. These elements such as $\mathrm{Fe}, \mathrm{Mn}, \mathrm{Pb}, \mathrm{Cu}, \mathrm{Mn}, \mathrm{Zn}, \mathrm{Co}$ and $\mathrm{Cr}$ known to be purposely added as colorants, whilst $\mathrm{As}$ and $\mathrm{Sb}$ are elements added as pacifiers for the glass making process. The result shows that green glass beads have higher amounts of copper and lead contents. Usually lead contents are higher than copper. Blue glass beads have higher copper contents whilst yellow glass beads have higher lead contents. The red glass beads have higher amount of copper content which are 2661 and 2240 ppm respectively and also high content of forum that is 2.74 and $2.03 \%$ respectively. The orange and brown glass beads also have a very high content of cooper that is more than $1 \%$ and forum that is more than $3 \%$.

In Table 5, Rahman et al. (2008) stated that only one sample (331F) was found to contain higher concentration of iron, while the rest of the sample contained iron of less than $2 \%$. The sample is also higher in manganese that is $3136 \mathrm{ppm}$ or $0.3 \%$. However other black sample, which is coded as 1239A, does not show higher level of iron. The content of its iron and other elements in the sample are comparable and show no significant difference from the other glass bead samples. This may be due to the reason that, apart from the chemical colorants the colour of glass beads is also dependent on the present other ingredients, temperature change and the atmospheric oxidizingreducing conditions.

Only one bead shows high cobalt content that is the 331A blue bead; however it has relatively normal level of manganese content. Cobalt can produce the blue colour in the bead either in oxidizing and reducing atmosphere. Other glass beads with white stripe and dark blue colour $(331 \mathrm{G})$ also shows high contents of cobalt (394 ppm) compared to other blue beads. The sample also has high content of Mn (5430 ppm). Other glass beads with dark blue colour do not show elevated contents of $\mathrm{Co}$ or Mn. This signifies that the cobaltmanganese-potash dark blue glass of Arikamedu type is not found in the Sungai Mas beads. The opaque beads sample 331C, 331D, 331E and 331J were found to have elevated level of $\mathrm{As}$ and $\mathrm{Sb}$, both elements are known 
to be used as opacifier agent for the glass making industry. However other types of opaque glass beads such as 1239B, 1239C, 331H and 90B do not show elevated level of As or $\mathrm{Sb}$. It is important to note that $\mathrm{Sn}$, which is not analyzed in the study is also an element used as an opacifier agent by manufacturers of glass for bead making.

\section{CONCLUSION}

Based on the compositional analysis that has been done on the glass beads from Sungai Mas, Kedah the findings showed that Sungai Mas, Kedah produced their own glass to make Indo-Pacific beads. Indo-pacific beads found in Sungai Mas were locally made and did not originate from Arikamedu, India. OC-EO also produced their own glass to make Indo-Pacific beads and the compositional analyses showed that OC-EO glass beads are different from Arikamedu glass beads. Sungai Mas and OC-EO beads have higher amount of silver content compared with western glasses that has silver content below 5\%. Glass beads from OC-EO also have a lower concentration of silica compared with Sungai Mas glass beads. Compositional analyses on Sungai Mas and OC-EO glass beads have proved that Sungai Mas and OC-EO were two of the Indo-Pacific beads-making centres in Southeast Asia. The drawn monochrome glass beads were not from Arikamedu but were locally made. OC-EO was established as the Indo-Pacific beads centre from the 2 nd century $\mathrm{CE}$ to 7th century CE while Sungai Mas from the 7th century CE to 12 th century $\mathrm{CE}$.

\section{REFERENCES}

Abdullah, M.Z., A. Saat and Z. Hamzah, 2011. Optimization of energy dispersive $\mathrm{x}$-ray fluorescence spectrometer to analyze heavy metals in moss samples. Am. J. Eng. Applied Sci., 4: 355362. DOI: 10.3844/ajeassp.2011.355.362

Bachmann, H.G., 1982. The identification of slags from archaeological sites. 1st Edn., Institute of Archaeology, London, ISBN: 0905853105, pp: 37.

Bentley C.C., 1986. Indigenous states of Southeast Asia. Ann. Rev. Anthropol., 15: 275-305.

Davidson, C.C., 1972. Glass Beads in African Archaeology: Results of Neutron Activation Aanalysis, Supplemented by Results of X-Ray Fluorescence Analysis. University of California, California, pp: 361.

Francis Jr. P., 1985. A Survey of Beads in Korea. 1st Edn., Center for Bead Research, Lake Placid, NY. USA., ISBN: 0910995079, pp: 45.
Francis Jr. P., 1989. Beads and The Bead Trade in Southeast Asia. 1st Edn., Center for Bead Research, Lake Placid, N.Y., pp: 35.

Francis, P., 2002. Asia's Maritime Bead Trade 300 B.C to the Present. 1st Edn., University of Hawai'I Press, Honolulu, ISBN: 082482332X, pp: 305.

Hamzah, Z., S.D. Riduan and A. Saat, 2011. Determination of sediment profile for ${ }^{210} \mathrm{~Pb}, \mathrm{~Pb}, \mathrm{U}$ and Th from Sultan Abu Bakar Dam due to soil erosion from highland agriculture area, Cameron Highlands, Malaysia. Am. J. Environ. Sci., 7: 263268. DOI: 10.3844/ajessp.2011.263.268.

Hancock, R.G.V., A. Chafe and I. Kenyon, 1994. Neutron activation analysis of sixteenth-and seventeenth-century european blue glass trade beads from the eastern great lakes area of north america. Archeometry, 36: 253-266. DOI: 10.1111/j.1475-4754.1994.tb00968.x

Irāmacāmi, A., 1987. History of Pondicherry. Sterling Publishers, New Delhi, ISBN: 8120706455, pp: 296.

Lamb, A., 1965. Some glass heads from the Malay Peninsula. MAN., 65: 36-38.

Pelliot, P.M.P., 1903. Le fou-nan. 3: 248-303.

Rahman, S.A., M.S. Hamzah, A.K. Wood, M.S. Elias and K. Zakaria, 2008. INAA of ancient glass beads from sungai mas archaeological site, bujang valley, Malaysia. J. Radioanalytical Nuclear Chem., 278: 271-276. DOI: 10.1007/s10967-008-9501-8

Ramli, Z., N.H. Shuaimi and N.A. Rahman, 2009. Beads trade in peninsula Malaysia: Based on archaeological evidences. Eur. J. Soc. Sci., 10: 585-593.

Ramli, Z., N.H.S.N.A. Rahman and A.L. Samian, 2011. $\mathrm{X}$-ray fluorescent analysis on Indo-Pacific glass beads from Sungai Mas archaeological sites, Kedah, Malaysia. J. Radioanalytical Nuclear Chem., 227: 741-747. DOI: 10.1007/s10967-0100920-y

Sharmin, S., H.M. Zakir and N. Shikazono, 2010. Rare earth elements and geochemical partitioning of $\mathrm{Zn}$ and $\mathrm{Pb}$ in sediments of an urban river. Am. J. Environ. Sci., 6: 406-415. DOI: 10.3844/ajessp.2010.406.415

Sola, O. and A.A. Fatukasi, 2011. An appraisal of foreign exchange resources generation and management. J. Soc. Sci. 7: 579-585. DOI: 10.3844/jssp.2011.579.585

Solheim, W.G., 1963. L'archéologie du Delta du Mékong by L. Malleret. Artibus Asiae, 26: 74-78.

Turner, W.E.S. and H.P. Rooksby, 1959. studies in ancient glasses and glassmaking processes. J. Society Glass Technol., 40: 162T-186T. 